\title{
Validity Evidence of the Team Psychological Safety Survey
}

\author{
Maria Cecília Koehne Ramalbo ${ }^{1}$ \\ Juliana Barreiros Porto ${ }^{1}$ \\ ${ }^{1}$ Universidade de Brasilia, Brasilia, Distrito Federal, Brasil
}

\begin{abstract}
The objective of this study was to adapt and investigate validity evidence for the Team Psychological Safety Survey for Brazil and to test its feasibility to emerge at the team level. A sample of 8,310 female workers answered the scale. Initial analyses indicated the single-factor solution fitness, with Cronbach's alpha $=0.84$. Confirmatory factor analysis model obtained good fitness coefficients, $\mathrm{CFI}=0.995$, RMSEA $=0.07$. Emersion was viable due to group variance identified by and ICC calculations. The hypothesis stated that psychological safety correlates with perceived organizational practices and that differences exist between men and women's practices. Findings support that the good practices positively related to psychological safety, with differences between gender, while a negative relationship with bad practices was partially confirmed. A quadratic trend was identified between organizational status and psychological safety. Results provide validity evidence for the survey for samples of Brazilian women.

Keywords: gender; factor analysis; organizational status; work team; diversity
\end{abstract}

Evidências de Validade da Escala de Segurança Psicológica em Equipe

\begin{abstract}
Resumo
O presente estudo teve como objetivo a adaptação e investigação de evidências de validade da Escala de Segurança Psicológica em Equipe para o Brasil. A amostra foi composta por 8.310 trabalhadoras. Análises iniciais indicaram adequação da solução unifatorial, alfa de Cronbach =0,84. Análise confirmatória do modelo unifatorial obteve bons índices de adequação, CFI $=0,995$, RMSEA $=0,07$. ADMd e ICC indicaram que parte da variância é explicada pelo grupo, $\operatorname{ICC}(1)=0,195$, viabilizando a emersão do construto. Hipotetizou-se que a segurança psicológica teria correlações com a percepção de práticas organizacionais. Os achados sustentam que as boas práticas investigadas possuem relação positiva com o construto, sendo mais forte com as práticas adotadas por homens. A relação negativa com as más práticas foi parcialmente confirmada. Por fim, identificou-se uma tendência quadrática entre status organizacional e segurança psicológica. Os resultados oferecem evidências de validade da escala para amostras de mulheres brasileiras.

Palavras-chave: gênero, análise fatorial, status organizacional, equipe de trabalho, diversidade
\end{abstract}

\section{Evidencias de validez de la Escala de Seguridad Psicológica en Equipo}

\begin{abstract}
Resumen
El presente estudio tuvo como objetivo no solo adaptar e investigar las evidencias de validez de la Escala de Seguridad Psicológica en Equipo para la población brasileña, sino también probar su viabilidad para emerger a nivel de equipo. La muestra se compuso por 8.310 trabajadoras que contestaron la escala. Los primeros análisis señalaron la adecuación de la solución de un solo factor, $\alpha=0,84$. El modelo unifactorial del análisis factorial confirmatorio obtuvo buenos índices de adecuación, CFI = 0,995, RMSEA $=0.07$. ADMd e ICC indicaron que parte de la varianza se explica por el grupo, ICC $(1)=0,195$, viabilizando la emersión del constructo. Se planteó la hipótesis de que el constructo tendría correlaciones con la percepción de las prácticas organizacionales. Los hallazgos avalan que las buenas prácticas investigadas disponen de una relación positiva con el constructo, siendo más fuerte con las prácticas adoptadas por los hombres. La relación negativa con las malas prácticas se ha confirmado parcialmente. En conclusión, se identificó una tendencia cuadrática entre el estado organizacional y la seguridad psicológica. Los resultados proporcionan evidencias de validez de la escala para muestras de mujeres brasileñas.

Palabras clave: género; análisis factorial; estatus organizativo; equipo de trabajo; diversidad
\end{abstract}

The demand for individual contributions by employees to innovate their work processes, taking risks and engaging in problem-solving, affects all organizations, not just those in the creative market or adhocracies. Workers are evaluated for their active social participation in all kinds of organizations, especially those that depend on interdisciplinary teams, such as health and care organizations (Nembhard \& Edmondson, 2006). However, what conditions can promote these behaviors? The literature points out that work environments perceived as psychologically safe are more conducive to taking interpersonal risks, and are also related to organizational commitment, team conflict management, and performance and learning at work (Bradley, Postlethwaite, Klotz, Hamdani, \& Brown, 2012; Edmondson, 1999; Edmondson, 2002; Newman, Donohue, \& Eva, 2017; Singh, Winkel, \& Selvarajan, 2013). 
The psychological safety construct was initially coined to refer to an individual's perceived safety and confidence in the face of organizational change. This definition by Schein \& Bennis (1967) focuses primarily on employee anxiety in being minimally acceptable and useful in this context. Later, Kahn (1990) redefined it as the individual's perception of being able to engage in interpersonal relationships at work without fear of negative consequences for his or her self-image, status or career. Edmonson's (1999) definition is the most commonly used in the recent literature (Newman et al., 2017) and was adopted in this study. She defines team psychological safety as the shared trust that the team will not embarrass, reject or punish a member for speaking up or expressing him/herself freely.

Distinguishing between team psychological safety and group cohesion is essential. Both are emergent group phenomena, but cohesion is an affective state while psychological safety is primarily cognitive (Bradley et al., 2012). Cohesion ultimately reduces the occurrence of internal disagreements and criticism against other members' ideas because of low levels of interpersonal risk in the group (Bradley et al., 2012; Edmondson, 1999). The psychological safety of the team is not only the result of interpersonal trust, as is the case of high cohesion, which sometimes translates into permissiveness and leniency among group members. Psychological safety stems from the feeling that, beyond trust, there is interpersonal respect and that these will continue even after the expression of personal ideas. In the seminal work by Edmondson (1999), the results confirm that the construct goes beyond interpersonal trust, being a mixture of trust, care for the other as a person and respect for each member's competences.

\section{The team psychological safety survey}

Edmondson's (1999) measure, originally in English, contains two belief subscales: team psychological safety and team effectiveness; and two behavioral subscales about team learning. The adaptation described here refers only to the team psychological safety subscale. For this decision, we considered that measures already exist in Brazil both for team learning (Barouh \& Puente-Palacios, 2016) and team power (Borba, 2007), a construct close to effectiveness. Both power and effectiveness refer to a shared belief about the team's ability to perform tasks, distinguishing itself by the degree of generalization of the investigated task (for the definition of the team power constructs and scale see Borba, 2007).
The original survey (Edmondson, 1999) consisted of seven items expressing psychological safety to be evaluate on an agreement scale. The sample $(\mathrm{N}=427)$ consisted of 51 work teams from different sectors at a manufacturing company. The single-factor structure and validity of this survey were investigated through main components analysis with varimax rotation, obtaining a good internal consistency coefficient, $\alpha=.82$. The emergence of psychological safety at the group level was performed based on the intraclass correlation coefficient, $\mathrm{ICC}=.39, \mathrm{~F}(50,427)=6.98, \mathrm{p}<.001$.

The literature presents different versions of the psychological safety survey with good internal consistency coefficients (Edmondson, 1999; Garvin, Edmondson, \& Gino, 2008; Nembhard and Edmondson, 2006), supporting the robustness of the construct. The most recent version was found in Garvin et al. (2008), with five items. In contact with one of the authors, it was informed that the scale has a Cronbach's alpha reliability coefficient of .94 (A.C. Edmondson, personal communication, July 30th, 2018). In the study by Nembhard and Edmondson (2006), they used an adapted four-item version $(\alpha=.73)$. The emersion of the variable for the group level was performed with ICC based on ANOVA, F $(22,1366)=8.62, \mathrm{p}<.001$ and $\mathrm{rCIC}=.21$. Tucker, Nembhard, and Edmondson (2007) used a three-item adaptation $(\alpha=.74)$. They added the scores to the team level after calculating the internal agreement coefficient $\left(r_{-} W G=.71\right)$ and significance of ICC [1] $=.30$ and ICC [2] $=.81$. These previous adaptations had different versions of the scale but brought no justifications for varying item quantities. The six-item version was chosen due to it being the version chosen by original author to be available in a public database. This decision was supported by the original author in the aforementioned communication. Validity comparisons of the different versions are recommended for further investigations.

\section{Psychological safety and analysis levels}

In a systematic review of the literature, Newman, Donohue, and Eva (2017) found several studies that support psychological safety as a multilevel phenomenon. Twenty-nine studies were carried out with psychological safety measures at the individual level, 42 at the team level and only two at the organizational level. Among all articles, the most used measure, in the full, short or adapted versions, was the psychological safety subscale, present in Edmondson's (1999) Team Learning and Psychological Safety Survey. All 
team-level psychological safety studies aggregated individual perceptions based on high intraclass correlation coefficients (ICC).

At the group level, we refer to psychologically safe groups (Edmondson, 1999), psychologically safe work environments (Edmondson \& Lei, 2014; Newman et al., 2017) and psychologically safe or welcoming climates (Bradley et al., 2012; Singh et al., 2013). These environments enhance the worker's sense of union with work and the team, improving the quality of social interactions and enhancing organizational learning, performance, and innovation (Edmondson \& Lei, 2014; Newman et al., 2017), as well as engagement in prescribed and organizational citizenship behaviors (Singh et al., 2013). Edmondson and Lei (2014) suggest that the psychological safety construct is essentially groupbased. The authors consider that, even in organizations with an influential culture, teams from the same organization differ from one another in terms of perceived safety (p. 30).

The team psychological safety, belonging to the meso level, originates from individual perceptions about a common referent, one's group. After emerging, the construct becomes independent of one or another member of the group but maintains a dynamic relationship of mutual influence with the individual level (Puente-Palacios, Porto, \& Martins, 2016). The consensus model has been the most widely used to measure the psychological safety of the team, but there is a lack of research on the strength of team safety and the variables that make team members possess different beliefs (Newman et al. 2017). Considering past empirical findings of different levels of psychological safety, we derived the hypothesis:

Hypothesis 1: The team psychological safety emerges from the individuals' shared perception (H1).

\section{Psychological safety and the nomological network}

At the individual level, the perceived psychological safety refers to the safety to express opinions, ideas and taking risks without being judged in a given social environment (Edmondson \& Lei, 2014). Individual and dyadic consequences of psychological safety are both behavioral, such as improved communication and proactive expression of ideas and opinions, and increased creativity and performance; and attitudinal, such as engagement, commitment, and empowerment (Edmondson \& Lei, 2014; Newman et al., 2017). Relationships between individual psychological safety and self-efficacy are also predicted. There are indications that both constructs are influenced by, or influence, shared variables such as leader-promoted inclusion (Bienefeld \& Grote, 2014; Nembhard \& Edmondson, 2006; Randel, Dean, Ehrhart, \& Chung, 2016), social status at work (Bienefeld \& Grote, 2014; Gecas, 1989; Tucker et al., 2007), creativity (Edmondson \& Lei, 2014; Lee, Choi, \& Kim, in print; Ma, Cheng, Ribbens, \& Zhou, 2013; Wang, Liu, \& Zhu, 2018; Wong, Chow, Lau, \& Gong, 2018) and learning (Deng, Leung, Lam, \& Huang, 2017; Edmondson, 2002; Ortega, Van den Bossche, Sánchez-Manzanares, Rico, \& Gil, 2014). Based on the theoretical relationship between psychological safety and self-efficacy, as correlated but not similar constructs, we expect that:

Hypothesis 2: Psychological safety is moderately and positively related to self-efficacy (H2).

The psychological safety of the work team is a variable of interest in the investigation of groups with diversity, in sociodemographic (Kirkman, Cordery, Mathieu, Rosen, \& Kukenberger, 2013) as well as informational (Nembhard, Edmondson, 2006) terms. The literature points out that some of the leading causes of psychological safety in the organizational context are the sense of belonging to the closest social group and the quality of the personal relationships of employees with colleagues and external parties, such as suppliers, customers, partners, and others (Newman et al. al., 2017). These variables are also central to the investigation of the complex relationship between diversity and performance (Roberson, Ryan, \& Ragins, 2017). Newman et al. (2017) suggest that future studies on psychological safety consider social and organizational diversity as one of the variables that affect the strength of the team's psychological safety, making the team members disagree in their perceptions.

A more significant impact of practices involving organizational diversity on psychological safety is expected when discrepancies in power occur, such as in relationships between members of different organizational status levels (e.g., leaders and subordinates) and different genders (Dasgupta, 2009; Mountian \& Rosa, 2015; Singh et al., 2013). Power issues permeate standard practices in the organization when they occur between members of different genders and, consequently, different social status levels. Nembhard \& Edmondson (2006) investigated the role of psychological safety in the relationship between the inclusion promoted by the leader and the team's engagement in improving the quality of work, also considering the effect of the organizational status on the relationships. The inclusion promoted 
by the leader, defined by the authors as the "words and actions of a leader, or leaders, that indicate invitation and appreciation for the contributions of others" (Nembhard \& Edmondson, 2006, p.947) was measured based on three behaviors: encouragement, respect and search for the opinions of team members with lower power status. The authors also investigated differences in psychological safety regarding diversity characteristics that varied in terms of their proximity to the work: gender, status, and tenure in the organization. Status and career tenure are variables closer to work, referring to a diversity of organizational hierarchical position and distribution of social resource (power), while gender is a more distant variable, referring to demographic diversity (Pelled, Eisenhardt, \& Xin, 1999; Roberson et al., 2017; van Knippenberg \& Schippers, 2007).

In Nembhard and Edmondson's (2006) survey, individual psychological safety was significantly predicted by status, marginally predicted by tenure in the organization, while gender had no significant relationship. Positive relationships were also found between inclusion promoted by the leader and team engagement in improving work quality $\left(\mathrm{R}^{2}=0.33, \mathrm{p}=0.004\right)$, and between inclusion and team psychological safety $\left(\mathrm{R}^{2}=\right.$ $0.55, \mathrm{p}<0.001)$. A significant contribution of the study is that, in the mediation model, leadership-based prediction of engagement became non-significant, while psychological safety remained significant $(B=0.57, \mathrm{p}$ $=0.03$ ). This study supports the hypothesis that psychological safety mediates the relationship between inclusion promoted by the leader and engagement in improving work quality, and evidences the importance of psychological safety when we analyze individuals with different organizational and social status levels.

Singh et al. (2013) investigated the mediating power of psychological safety in the relationship between diversity climate and performance. They raised the hypothesis that race moderates both the impact of the diversity climate on psychological safety and the effect of safety on performance. As expected, the authors found a positive relationship between diversity climate and psychological safety, between psychological safety and organizational (OCBO) and interpersonal citizenship behavior (OCBI). The relationship between psychological safety and intra-role behavior was only partially confirmed. The results of the moderated mediation indicated that psychological safety has a mediating influence on the relationship between climate and OCBO and OCBI. The moderation of race in the relationship between diversity climate and psychological safety rested on the significant interaction between race and climate. The relationship between psychological security and OCBO was also moderated by race, indicating that the effects of the relationship are stronger for minorities.

The results of Singh et al. (2013) support the theory that psychological safety is a core variable to obtain good results based on diversity. As presented, leaderpromoted inclusion practices, as well as the perception of diversity-related organizational practices of inclusion and exclusion, affect psychological safety. Thus,

Hypothesis 3: Psychological safety is positively related to organizational support practices regarding the recognition and incentive of competences and respect for the room to speak $(\mathrm{H} 3)$.

Hypothesis 4: Psychological safety is negatively related to practices of appropriation of ideas and denial of room to speak in the workplace (H4).

Considering that all respondents are female and the possible effect of organizational and social status on the individual perception of psychological safety, we raise:

Hypothesis 5: The relationships predicted in $\mathrm{H} 3$ and $\mathrm{H} 4$ will be stronger when the author of the practices is male (H5).

Hypothesis 6: The level of psychological safety increases according to the status of the position held in the organization (H6).

Despite the practical and theoretical importance of the psychological safety construct, no measures were found that evaluated the perceived team psychological safety adapted to Brazil. Thus, we contribute to fill this gap in the area through the adaptation of the 6-item version of the Edmondson Team Psychological Safety scale (1999) and present its validity evidence of the internal structure and nomological convergent validity in the Brazilian population. WE also investigate: 1) the ability of the construct to emerge to the group level; 2) its relationship with organizational status, when comparing individuals with and without management positions; and 3) the correlation, at the individual level, of psychological safety with the perception of organizational diversity practices.

\section{Method}

\section{Measures}

The adapted survey was the version of Edmonson's (1999) Team Learning and Psychological Safety Survey, composed of six items, available in the Measurement Instrument Database for the Social Sciences 
- MIDSS, by indication of the original author (AC Edmondson, personal communication, July $30^{\text {th }}, 2018$ ). We used the guidelines of the International Test Commission (Hambleton, 2004) to adapt the scale. Initially, we translated the English version into Portuguese with the help of an external collaborator knowledgeable on psychometrics and English language. One of the translated items ("It is completely safe to take a risk on this team") was biased, for it was possible to translate as both as a perception of safety for oneself and as a perception of safety in general. To solve this problem, we elaborated three versions of the item in Portuguese, ranging from the most similar to the original to the most comprehensible as subject oriented in Brazilian Portuguese. Then, a sworn translator performed the back-translation of the items to English. All items, including the three-version item, were compatible with the original measure, allowing us to use the most comprehensible translation. After the translation stage, the measure underwent a pilot test to verify the face validity, in which no semantic or face problems were found. Table 1 presents the final version of the items in Portuguese that should be answered on an agreement scale ranging from 1 to 5 (1 - I totally disagree; 2 - I disagree more than I agree; 3 - I neither agree nor disagree; 4 - I agree more than I disagree; 5 - I totally agree).

In order to measure self-efficacy, the Perceived General Self-Efficacy (EAGP) scale was used, adapted to Brazil by Gomes-Valério (2016). The Cronbach's alpha in our sample $(n=8,310)$ was .86 . The occurrence of organizational support practices about gender equality and sexist practices at work were identified based on ten items, to be answered on the same agreement scale used for the psychological safety measure (Table 2). All questions were mirrored to refer to the practices of male and female managers and colleagues.

\section{Sample}

Self-identified female employees were invited to participate in the study. The sample consisted of 8,310 respondents between 20 and 78 years old, mean age 40 years $(\mathrm{SD}=8.4), 3.3 \%$ of the respondents came from the North of the country, $11.4 \%$ from the Northeast, $19.2 \%$ from the South, $20.9 \%$ from the Midwest and $45.2 \%$ from the Southeast. Most respondents were Caucasian $(75 \%)$ or black $(21 \%)$. Employees with disabilities accounted for $1.22 \%$ of the sample. Regarding the organizational status of the position held, $25.9 \%$ of the respondents did not have any supervision position, $46.4 \%$ had a non-management bonus function (e.g., treasury or cashier), $23.1 \%$ a management position and $4.6 \%$ a service head position. The most prevalent level of education was latu sensu (50\%), followed by higher education (39\%); 7\% have secondary education, and there were no respondents with a lower education level. Regarding family characteristics, $49 \%$ is married, and $68.5 \%$ has dependents.

\section{Data Collection Procedures}

The data collection was carried out in a public bank. The questionnaire was sent to all female employees in the organization, from all states of the Brazilian federation, via the intranet. Before answering the questionnaire, participants were asked to complete an Informed Consent Form.

\section{Data analysis procedures}

The analyses were developed in R software, using the "cocor", "psych", "lavaan", "sem" and "nlme" packages (Bliese, 2016; Diedenhofen \& Musch, 2015; Fox, 2006; Revelle, 2018; Rosseel, 2012). The complete response database $(\mathrm{n}=8,310)$ was randomly divided into two parts of $n=4155$. There were no incomplete cases in the completion of the psychological safety survey as the answers were mandatory. A random data division procedure is advisable to compare different factor analyses in a sufficiently large database (Fabrigar, 1999).

In one half of the base, we conducted a principal component analysis (PCA) to calculate the number of factors to be extracted, followed by an exploratory factor analysis (EFA), using polychoric correlations and weighted least squares (WLS) estimation, in the other half, we used confirmatory factor analysis (CFA) with estimation by the robust weighted least squares (WLSMV), a suitable method for ordinal data and less subject to bias (Li, 2015). For goodness of fit criterion, we adopted the recommendation by Schreiber et al. (2006): CFI > 0.95; TLI $>0.95$ and; RMSEA $<0.08$, considering the margins of the confidence interval.

After the factor analyses, we calculated the mean scores of each participant. The emersion of the construct was verified by calculating the intraclass correlation coefficients - ICC, and the mean deviation indices of the groups to the median ( $\left(\left(\mathrm{AD} \rrbracket \_\mathrm{Md}\right)\right.$. Burke, Finkelstein, and Dusig (1999) recommend [AD』_Md as a pragmatic index of inter-respondent agreement. The indices are considered significant in practice when their coefficients are inferior to $\mathrm{A} / 6$, with $\mathrm{A}$ being the number of alternative answers in the scale (Bliese, 2016). The aggregation of the scores of the scale versions has 
been done mainly based on the obtention of a high ICC (Newman et al., 2017). Bliese (2000) describes that there are two main ways of calculating the intraclass correlation index, the ICC(1), also called ICC or ICC(1.1) and ICC(2) or ICC(k ). The ICC(2) represents the reliability of the mean of a group, while the ICC(1) is the total variance explained by belonging to the group. The ICC estimates were calculated on the basis of the average score of the respondent team members whose 【AD】_Md was inferior to the ceiling. Two ICC(1) were calculated, using the ANOVA and the RMLE method (Bliese, 2000).

Hypotheses 2, 3 and 4 were tested based on the significance of the correlations between variables. To investigate $\mathrm{H} 5$, we verified the difference between the correlations of psychological safety with each question pair with a female and male referent. H6, regarding the relationship between psychological safety and organizational status, was investigated in a one-way analysis of variance model with orthogonal contrasts designed for intergroup differences with different organizational statuses. It was also possible to test for trends in the relationship, as there were four increasing function levels in the organization as a classification of organizational status. Also, we performed a t-test to ascertain differences in psychological safety between the participants who had already entered internal selection processes for management positions and those who had never tried.

\section{Results}

Analysis of the internal structure of the Team Psychological Safety Survey

The initial analyses of assumptions indicated that some survey items presented a non-normal distribution due to kurtosis, even though the results indicated the fitness of the data for factor analysis. The survey showed to be factorable $(\mathrm{KMO}=.87$ and Bartlett Sphericity <0.001). Next, a principal component analysis (PC) was performed, which indicated only one factor with an eigenvalue greater than 1, explaining $56 \%$ of the variance. The criterion of Velicer's minimum mean partial correlations was reached with one factor (MAP = 0.047). Finally, a parallel analysis was performed, which also indicated the single-factor solution.

An exploratory factor analysis with extraction by the principal axis factoring method (PAF) permitted retaining all six items, with factor loadings varying between .69 and .82. Items SP1, SP3, and SP5 were inverted and had a negative loading in the single factor (see Table 1). The internal consistency of the scale was good, Cronbach's alpha $=.84$.

The confirmatory factor analysis was performed in the second half of the database. The model tested had good fit indices (Schreiber et al., 2006), with no indications of necessary modification: $\chi 2(9)=205,273$; $\mathrm{CFI}=.995 ; \mathrm{TLI}=.992 ; \mathrm{RMSEA}=.07[.064 ; .081]$.

\section{Hypothesis test}

For the test of emersion, the cases containing the identification of the work team were selected, and all groups with less than three members were withdrawn. The final base consisted of 2866 respondents, distributed among 616 groups. Then, the mean deviation indices of each group were calculated to the median ( [AD】_Md) of the psychological safety score. As the scale ranged from 1 (totally disagree) to 5 (totally agree), the limit of .83 was set for [AD】_Md. Then, we verified that the mean [AD】_Md scores were inferior to the maximum index $(\mathrm{M}=.664, \mathrm{sd}=.19)$. Groups that exceeded the limit were eliminated, leaving 470 groups

Table 1.

Factor Loading of the Items in the Team Psychological Safety Survey

\begin{tabular}{|c|c|}
\hline Item & $\begin{array}{c}\text { Factor } \\
\text { Loading }\end{array}$ \\
\hline Nessa equipe, quando alguém comete um erro é comum que isso seja usado contra ela no futuro. & -0.698 \\
\hline É fácil discutir problemas ou questões difíceis nessa equipe. & 0.703 \\
\hline Nessa equipe as pessoas são rejeitadas por serem diferentes. & -0.758 \\
\hline Assumir riscos é completamente seguro nessa equipe. & 0.769 \\
\hline É difícil pedir ajuda a outros membros dessa equipe. & -0.668 \\
\hline Membros dessa equipe respeitam e valorizam as contribuições uns dos outros. & 0.815 \\
\hline
\end{tabular}


with a value equal or inferior to .83. The ANOVA method ICC(1) was .193, and the RMLE method ICC(1) was .195. The calculations of [AD】_Md and ICC support H1, i.e., that the psychological safety construct can also be established at the group level.

The participants' mean scores were calculated to measure the correlations between psychological safety and the self-efficacy, competence recognition practices, competency-building incentive and room to speak, and practices of idea appropriation in the workplace. These analyses were performed at the individual level. In H2, we affirmed that there would be a moderate correlation between psychological safety scores and self-efficacy.
The correlation was small but significant, $\mathrm{r}=0.136$, 95\% CI [0.11; 0.164], $\mathrm{p}=0.01$, thus providing partial support for $\mathrm{H} 2$.

As predicted in $\mathrm{H} 3$, there were positive correlations between psychological safety and practices of competence recognition, competency-building incentive and room to speak (Table 2). H4 was partially sustained, with negative correlations between psychological safety and occurrence of speech interruption, while correlations with idea appropriation practices were low or non-significant (Table 2).

H5 pointed out that the correlations would be stronger for practices with male referents. All

Table 2.

Correlations between the Team Psychological Safety Survey and Organizational Practices

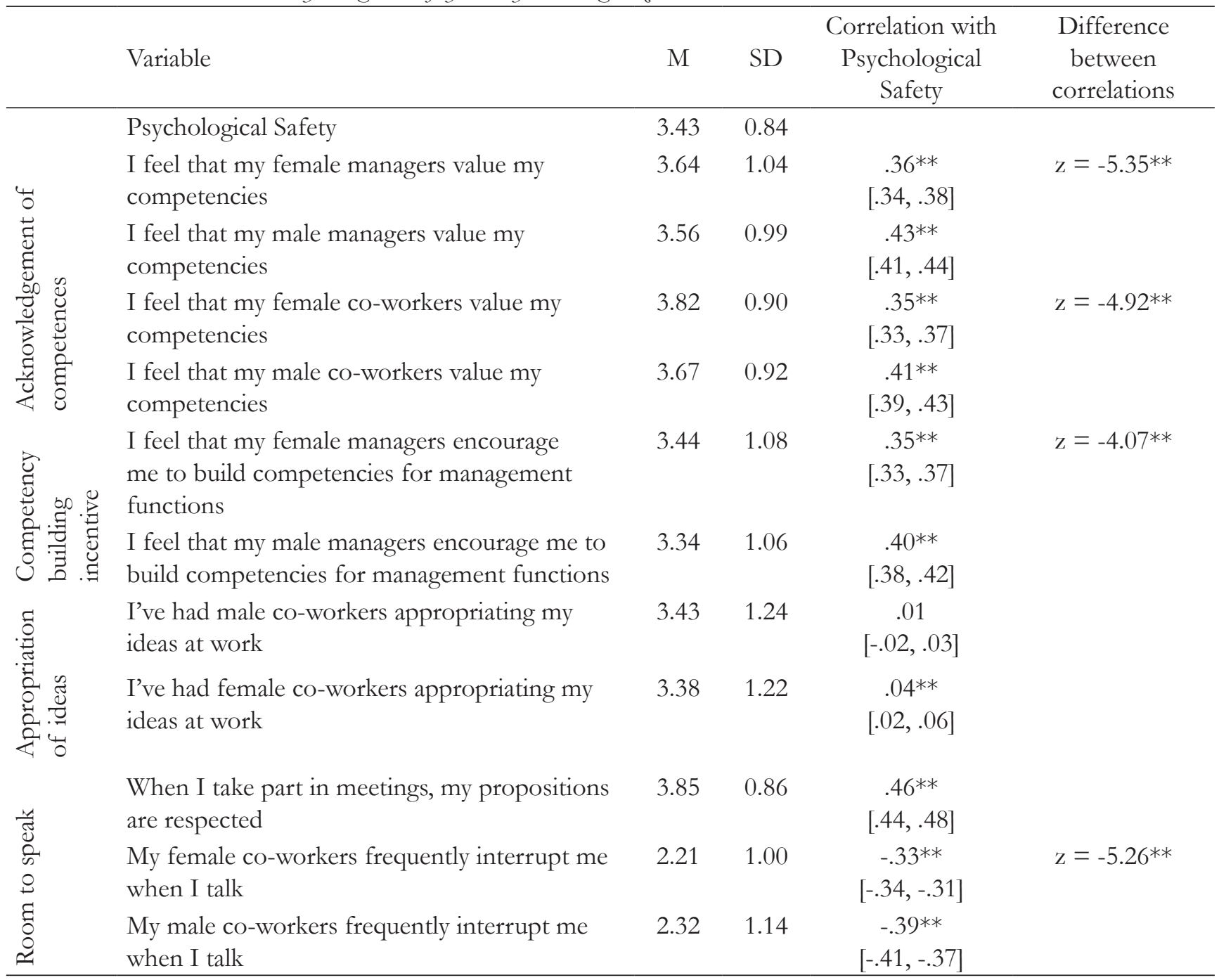

Note. ${ }^{*} \mathrm{p}<.05 ;{ }^{* *} \mathrm{p}<.01 . \mathrm{M}$ and $\mathrm{SD}$ are used to represent means and standard deviations, respectively. The coefficients between square brackets indicate the $95 \%$ confidence interval for each correlation. 
correlations were stronger for these aspects, except for the practice of appropriating ideas by men, which did not correlate with psychological safety. One-tailed tests indicated that the differences between the correlations were significant in the $99 \%$ confidence interval (Table 2), allowing the rejection of the null hypothesis.

H6 affirmed that organizational status would positively affect psychological safety. ANOVA was applied to compare the scores of the employees serving as service heads, employees with a bonus function management position, with non-management bonus functions, and those with no bonus functions. The homogeneity of the variances was not confirmed due to the different sizes of the groups. Therefore, the corrected version of Brown-Forsythe's $F$ was used to check the equality of means (Field, 2015). The difference among the organizational functions was significant, $=41.978, \mathrm{p}<$ .00001 . All planned orthogonal contrasts indicated significant intergroup differences $(\mathrm{p}<.05)$. The differences of means (Figure 1) presented a significant quadratic trend, $=18.956, \mathrm{p}<.0001$.

Besides, the difference in psychological safety between participants who had already participated in internal selection processes for management $(\mathrm{M}=$ 3.46) and those who had never participated $(\mathrm{M}=3.38)$ also supported H6. The mean intergroup difference was significant in the $99 \%$ confidence interval, $t(5597)$ $=3.189, \mathrm{p}=0.01$.

\section{Discussion}

The objective of this study was to adapt the Team Psychological Safety Scale for Brazil and to gather initial evidence of the validity of the internal and convergent nomological structure in a sample of Brazilian workers.
After exploratory and confirmatory factor analyses, it was observed goodness of fit for the single-factor model tested, supporting the structure found in the other studies (Edmondson, 1999; Garvin et al., 2008; Nembhard \& Edmondson, 2006; Tucker et al., 2007). The internal consistency index of the scale $(\alpha=.84)$ was good. All items were retained due to its positive influence on the internal consistency. We do not recommend the use of shorter versions of the scale, once it is already a brief scale and all six items were significant, though we suggest further studies to investigate validity evidences of longer versions of the Psychological Safety Scale and comparisons between the different versions found in literature. These results indicate the adequacy of the scale for use in research and diagnosis.

The concurrent validity with self-efficacy was only partially sustained, with a weak correlation between constructs. One possible justification for the magnitude of this relationship is that, in the organizational context, variables external to the individual may influence the perceived psychological safety in the team more strongly than individual psychological characteristics.

Some of the hypotheses tested sought to investigate aspects of the relationship between individual psychological safety and external variables. The correlations with the perception of positive and negative practices of male and female co-workers and managers were investigated. As predicted, significant positive relationships were found with all good practices tested. Among the negative practices, however, only the interruption of speech was significantly related. These findings add to Singh et al. (2013), supporting the hypothesis that organizational practices aimed at the integration of minorities impact the psychological security of the teams. These findings, as well as those of

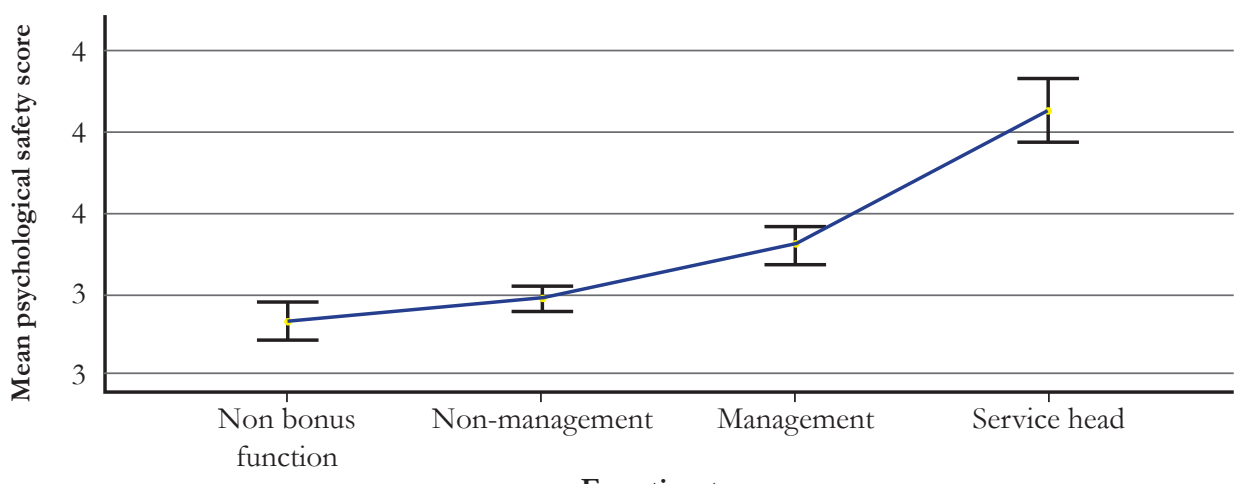

Function type

Figure 1. Planned function indices 
Nembhard and Edmondson (2006), Nishii and Mayer (2009) and Singh et al. (2013), argue that the psychological safety of minorities influences the relationship between organizational practices of inclusion and collecting the benefits of group diversity. Thus, psychological safety is an important variable for understanding diversity and inclusion in organizational settings and should be tested as a mediator of the relationship between diversity practices and their outcomes.

We also aimed to investigate the possible influences of social and organizational power on the construct. The participants' psychological safety increased significantly according to the organizational status of the position held, sustaining the positive relationship between psychological safety and organizational power. This positive interaction is in line with the results of Bienefeld \& Grote (2014) and Nembhard \& Edmondson (2006). Since we conducted a correlational study we cannot determine if power enhances the psychological safety or vice-versa. Future studies should explore this idea because of its influence on the decision of assuming higher positions in an organization. One challenge to HR professionals is to increase the number of minorities in leading positions. If psychological safety is an antecedent, it may be an additional relevance for the construct and a relevant variable for achieving this goal.

About sociodemographic diversity, we found that the correlations between the participants' psychological safety and the practices of male managers and co-workers were significantly higher than the correlations with the practices of female managers and co-workers. These results are consistent with the findings of Singh et al. (2013) and Kirkman et al. (2013), who point out that, the higher the psychological safety in the group, the higher the benefits derived from diversity. Finally, although the relational hypotheses tested were at the individual level, the viability of constructing the meso level was investigated. Tests of absolute deviation from the median and intraclass correlation coefficients indicated that, as expected in the literature, psychological safety is a personal construct that can emerge to the team level. The results of this emersion are compatible with previous findings in the literature (Edmondson, 1999; Nembhard \& Edmondson, 2006; Tucker et al., 2007).

\section{Final considerations}

This study presented validity evidence of the Team Psychological Safety Scale for samples of Brazilian women. The exploratory and confirmatory factor analyses indicated the goodness of fit of the singlefactor structure, while intraclass correlation analyses supported the emersion of the construct to the team level. Additionally, the relationship found with self-efficacy indicates that the constructs discriminate, but are correlated. Regarding the influence of organizational practices, positive relationships of the encouragement and recognition of competences with individual psychological safety, and negative relations with practices of disrespect for the room to speak were identified. In addition, these effects were significantly stronger when there was a gender difference between the participant and the practitioner of the practice under investigation. These results, as well as the growing relationship identified between psychological safety and organizational status, point out that psychological safety is permeated by relational issues of both social and organizational power. On the whole, the results contribute to identifying the factors that affect individual perceptions of psychological safety in the same team, contributing to inputs for future research on the strength of psychological safety in teams.

Despite these contributions, the results should be generalized with caution because, in addition to the sample including only women, we highlight that only workers in the banking sector were included, leading to a limitation concerning the professional diversity of the respondents. Future studies should seek additional evidence in more diverse samples in terms of gender and work context. Despite these limitations, the scale presented good indicators that suggest its use to broaden the studies on the antecedents and consequences of psychological safety.

Throughout this article, we tried to point out practices and relational aspects that influence psychological safety within the team. As argued at the beginning, psychological safety can be used to maximize the benefits of diversity within a team, especially when power issues such as status or gender are considered in relation to the practices of managers and collaborators. Thus, this research contributes to the study of the phenomenon in Brazil by bringing evidence of validity for the scale, and it is expected to contribute to future studies on this phenomenon.

\section{References}

Bienefeld, N., \& Grote, G. (2014). Speaking up in ad hoc multiteam systems: Individual-level effects of psychological safety, status, and leadership within 
and across teams. European Journal of Work and Organizational Psychology, 23(6), 930-945. https://doi. org/10.1080/1359432X.2013.808398

Bliese, P. (2000). Within-group agreement, non-independence, and reliability: Implications for data aggregation and analysis. Multilevel Theory, Research, and Methods in Organizations: Foundations, Extensions, and New Directions.

Bliese, P. (2016). Multilevel Modeling in R (2.6). An Introduction to $\mathrm{R}$ Notes on $\mathrm{R}$ : A Programming Environment for Data Analysis and Graphics.

Borba, A. C. (2007). Potência em equipes: desenvolvimento de uma medida. Universidade de Brasília Instituto. Retrieved from http://www.repositorio.unb.br/ bitstream/10482/3119/1/2007_AnaCristinaPortmannBorba_textoparcial_sem_anexos.PDF

Bradley, B., Postlethwaite, B., Klotz, A., Hamdani, M., \& Brown, K. (2012). Reaping the benefits of task conflict in teams: The critical role of team psychological safety climate. Journal of Applied Psychology, 97(1), 151-158. https://doi.org/10.1037/ a0024200

Burke, M., Finkelstein, L., \& Dusig, M. (1999). for Estimating Interrater Agreement. Organizational Research Methods, 2(1), 49-68.

Chrobot-Mason, D., \& Aramovich, N. (2013). The Psychological Benefits of Creating an Affirming Climate for Workplace Diversity. Group and Organization Management. https://doi. org/10.1177/1059601113509835

Dasgupta, N. (2009). Mechanisms underlying the malleability of implicit prejudice and stereotypes: The role of automaticity and cognitive control. In Handbook of prejudice, stereotyping, and discrimination (pp. 267284). https://doi.org/10.4324/9781841697772. $\operatorname{ch} 13$

Deng, H., Leung, K., Lam, C. K., \& Huang, X. (2017). Slacking Off in Comfort:A Dual-Pathway Model for Psychological Safety Climate. Journal of Management, 20(10), 1-31. https://doi. org $/ 10.1177 / 0149206317693083$

Diedenhofen, B., \& Musch, J. (2015). Cocor: A comprehensive solution for the statistical comparison of correlations. PLOS ONE. https://doi. org/10.1371/journal.pone.0121945
Edmondson, A. (1999). Psychological Safety and Learning Behavior in Work Teams. Administrative Science Quarterly, 44(2), 350-383. https://doi. org/10.2307/2666999

Edmondson, A. (2002). Managing the risk of learning: Psychological safety in work teams. International Handbook of Organizational Teamwork, 1-38. https:/ / doi.org/10.1026/0932-4089.48.3.158

Edmondson, A., \& Lei, Z. (2014). Psychological Safety: The History, Renaissance, and Future of an Interpersonal Construct. Annual Review of Organizational Psychology and Organizational Behavior, 1(1), 23-43. https://doi.org/10.1146/ annurev-orgpsych-031413-091305

Field, A. (2015). Discovering Statistics Using IBM SPSS Statistics. Statewide Agricultural Land Use Baseline 2015, 1.

Fox, J. (2006). Structural equation modeling with the sem package in R. Structural Equation Modeling. https://doi.org/10.1207/s15328007sem1303_7

Garvin, D., Edmondson, A., \& Gino, F. (2008). Is Yours a Learning Organization? Harvard Business Review. Retrieved from https://hbr.org/2008/03/ is-yours-a-learning-organization

Gecas, V. (1989). The Social Psychology of Self-Efficacy. Annual Review of Sociology, 15(1), 291-316. https:/ / doi.org/10.1146/annurev.so.15.080189.001451

Gomes-Valério, J. O. (2016). Apresentação da Versão Brasileira Definitiva da Escala de Autoeficácia Geral Percebida. Juiz de Fora. Retrieved from http://www. ajepsi.com.br/revista/site/uploads/publicacoes/443/14771569881.pdf

Kahn, W. (1990). Psychological Conditions of Personal Engagement and Disengagement At Work. Academy of Management Journal, 33(4), 692-724. https:/ / doi.org/10.2307/256287

Kirkman, B. L., Cordery, J. L., Mathieu, J., Rosen, B., \& Kukenberger, M. (2013). Global organizational communities of practice: The effects of nationality diversity, psychological safety, and media richness on community performance. Human Relations. https://doi.org/10.1177/0018726712464076

Lee, H. W., Choi, J. N., \& Kim, S. (n.d.). Does gender diversity help teams constructively manage status conflict? An evolutionary perspective of status conflict, team psychological safety, and team 
creativity. Organizational Behavior and Human Decision Processes, 1-13. https://doi.org/10.1016/j. obhdp.2017.09.005

Ma, Y., Cheng, W., Ribbens, B. A., \& Zhou, J. (2013). Linking ethical leadership to employee creativity: Knowledge sharing and self-efficacy as mediators. Social Behavior and Personality, 41(9), 1409-1420.

Mountian,I., \& Rosa, M. D. (2015). O outro: análise crítica de discursos sobreimigração e gênero. Psicologia USP. https://doi.org/10.1590/0103-6564D20150001

Nembhard, I., \& Edmondson, A. (2006). Making it safe: the effects of leader inclusiveness and professional status on psychological safety and improvement efforts in health care teams. Journal of Organizational Behavior, 27(7), 941-966. https://doi.org/10.1002/ job. 413

Newman, A., Donohue, R., \& Eva, N. (2017). Psychological safety: A systematic review of the literature. Human Resource Management Review, 27(3), 521-535. https://doi.org/10.1016/j.hrmr.2017.01.001

Nishii, L. H., \& Mayer, D. M. (2009). Do inclusive leaders help to reduce turnover in diverse groups? The moderating role of leader-member exchange in the diversity to turnover relationship. Journal of Applied Psychology, 94(6), 1412-1426. https://doi. org $/ 10.1037 / \mathrm{a} 0017190$

Ortega, A., Van den Bossche, P., Sánchez-Manzanares, M., Rico, R., \& Gil, F. (2014). The Influence of Change-Oriented Leadership and Psychological Safety on Team Learning in Healthcare Teams. Journal of Business and Psychology, 29, 311-321. https://doi.org/10.1007/s10869-013-9315-8

Pelled, L., Eisenhardt, K., \& Xin, K. (1999). Exploring the black box: An analysis of work group diversity, conflict, and performance. Administrative Science Quarterly, 44(1), 1-28. https://doi. org/10.2307/2667029

Puente-Palacios, K. E., Porto, J. B., \& Martins, M. do C. F. (2016). A emersão na articulação de níveis em Psicologia Organizacional e do Trabalho. Revista Psicologia, Organizaçoes e Trabalho, 16(4), 358-366. https://doi.org/10.17652/rpot/2016.4.12603

Randel, A., Dean, M., Ehrhart, K., \& Chung, B. (2016). Leader inclusiveness, psychological diversity climate, and helping behaviors. Journal of Managerial
Psychology, 31(1), 216-234. https://doi.org/DOI 10.1108/JMP-04-2013-0123

Revelle, W. (2018). psych: Procedures for Personality and Psychological Research. Northwestern University, Evanston, Illinois, USA. Retrieved from https:/ / cran.r-project.org/package $=$ psych

Roberson, Q., Ryan, A. M., \& Ragins, B. R. (2017). The evolution and future of diversity at work. Journal of Applied Psychology, 102(3), 483-499. https://doi. org/10.1037/apl0000161

Rosseel, Y. (2012). lavaan: An R Package for Structural Equation Modeling. Journal of Statistical Software. https://doi.org/10.18637/jss.v048.i02

Schein, E., \& Bennis, W. (1967). Personal and Organizational Change Through Group Methods: The Laboratory Approach. Wiley. Retrieved from https://books. google.com.br/books?id=jg7eAQAACAAJ

Singh, B., Winkel, D., \& Selvarajan, T. (2013). Managing diversity at work: Does psychological safety hold the key to racial differences in employee performance? Journal of Occupational and Organizational Psychology, 86(2), 242-263. https:// doi.org/10.1111/joop.12015

Tucker, A., Nembhard, I., \& Edmondson, A. (2007). Implementing New Practices: An Empirical Study of Organizational Learning in Hospital Intensive Care Units. Management Science, 53(6), 894-907. https://doi.org/10.1287/mnsc.1060.0692

van Knippenberg, D., \& Schippers, M. (2007). Work Group Diversity. Annual Review of Psychology, 58(1), 515-541. https://doi.org/10.1146/annurev. psych.58.110405.085546

Wang, Y., Liu, J., \& Zhu, Y. (2018). Humble Leadership, Psychological Safety, Knowledge Sharing, and Follower Creativity: A Cross-Level Investigation. Frontiers in Psychology, 9(17), 1-9. https://doi. org/10.3389/fpsyg.2018.01727

Wong, Y., Chow, I., Lau, V., \& Gong, Y. (2018). Benefits of team participative decision making and its potential to affect individual creativity. Journal of Applied Social Psychology, 48(7), 369-376. https:// doi.org/10.1111/jasp.12517

Recebido em: 29/05/2019 Reformulado em: 10/02/2020 Aprovado em: 27/02/2020 
About the authors:

Maria Cecília Koehne Ramalho is a psychologist graduated from Federal University of Bahia (UFBa) and M.Sc. in Social, Organizational and Work Psychology from University of Brasilia (UNB). She currently works as a researcher and consultant in developing strategic HR policies.

CNPQ grant No. 129121/2014-2

ORCID: https://orcid.org/0000-0002-3594-9772

E-mail: cecilia.k.ramalho@gmail.com

Juliana Barreiros Porto holds a Ph.D. degree from University of Brasilia (UNB). She is an associate professor at the Institute of Psychology and is the coordinator of the graduate program in Social, Work and Organizational Psychology at University of Brasilia.

CNPq productivity grant No. 304015/2015-6

ORCID: https://orcid.org/0000-0001-9164-2719

E-mail: porto.juliana@gmail.com

\section{Contact:}

Universidade de Brasília, Campus Darcy Ribeiro

ICC Sul. Instituto de Psicologia. Sala AT-013

Brasília-DF, Brasil 